\title{
Books and Reviews Received
}

Cuadernos Americanos. Dir. Adalberto Santana Hernández, Ed. María Elena Rodríguez Ozán. Universidad Nacional Autónoma de México. 137/ 2011. 226 pp. ISSN 0185156X. From the area of literary research, it contains the following articles: F. Aínsa, Los guardianes de la memoria: novelar contra el olvido; C. Caufield, Movelando y leyendo: una inspiraciónal conocimiento lúcido; B. Pulido Herráez, Jicoténcal: una disputa entre la monarquía y la república; V. Hernández Landa Valencia, Los tempos de la historia en Los piratas del Golfo de Vicente Riva Palacio; K. González, Memorias entrecruzadas: La amortajada y Pedro Páramo; H. F. Vizcarra, Significación del espacio narrado en el ciclo Las cuatro estaciones de Leonardo Padura.

Cuadernos Americanos. Dir. Adalberto Santana Hernández, Ed. María Elena Rodríguez Ozán. Universidad Nacional Autónoma de México. 137/ 2011. 226 pp. ISSN 0185156X. From the area of literary research, it contains a number of articles on the topic of „El poema extenso latinoamericano“.

Debats. 1, 2012. Valencia: Institució Alfons el Magnànim, 97 pp. ISSN 0212-0585. Dir. Rosa María Rodríguez Magda). The main topic in this issue of the richly illustrated journal is "La nueva pedagogía". It also contains materials about Julio Cortázar, Saúl Yurkevich and Julio Silva.

Exemplaria classica. Journal of Classical Philology. Eds. Antonio Ramírez de Verger Guillermo Galán, Miryam Librán. Universidad de Huelva. 15 /2011. ISSN 16993225. The journal contains a great number of articles on classical literature and reviews on editions and monographs in this field, in Spanish, English, German, French, Italian.

Fokkema, Douwe. Perfect Worlds. Utopian Fiction in China and the West. Amsterdam: Amsterdam University Press, 2011. 448 pp. ISBN 97890-89643506.

Juvan, Marko. Literary Studies in Reconstruction. An Introduction to Literature. Frankfurt am Main, 2011. 282 pp. ISBN 978-3-631-6186-6.

Pensamiento literario español del siglo XX. 5. T. Blesa, J. C. Pueo, A. Saldaña, E. Sullà, eds. Zaragoza: Universidad de Zaragoza, 2011.269 pp. ISBN 978-84-15274-79-7.

Performing Poetry. C. Gräbner, A. Casas, eds. Amsterdam-New York: Rodopi, 2011. 293 pp. ISBN 978-90-420-3329-0.

Rilce. 28.1. Eds. Pilar Saiz Serreda, Rosalía Baena. Monográfico. Identidad y representación en el discurso autobiográfico. Pamplona: Universidad de Navarra, 2010. 345 pp. ISSN 0213-2370. (Dir. Víctor García Ruiz.)

Siglo XX. Literatura y cultura españolas. Revista Anual de la Cátedra Miguel Delibes. 7 / 2009. Dir. María Pilar Celma. Valladolid: Cátedra de Miguel Delibes, 2010, 274 pp., ISSN 1697-0659. It contains a great number of articles on Spanish literature and culture, mostly, in Spanish. 
Books and Reviews Received

Talviste, Katre. La poésie estonienne et Baudelaire. Paris: L'Harmattan, 2011. 333 pp. ISBN 978-2-296-56079-6.

The Atlantic Literary Review. (Ed. Rama Kundu). Volume 12, Number 1, 2011. ISBN 978-81.269-1563-73. It contains articles mainly on the topic of cultural colonization.

The Atlantic Literary Review. (Ed. Rama Kundu). Volume 12, Number 2, 2011. ISBN 978-81.269-1611-5. It contains a variety of articles for the most part on English literature and (Indian) literature in English.

The Atlantic Literary Review. (Ed. Rama Kundu). Volume 12, Number 3, 2011. ISBN 978-81.269-1663-4. It contains a variety of articles for the most part on English literature and (Indian) literature in English, with contributions on feminist, postcolonial and other issues.

The Atlantic Literary Review. (Ed. Rama Kundu). Volume 12, Number 4, 2011. ISBN 978-81.269-1674-0. It contains a variety of articles for the most part on English literature and (Indian) literature in English.

Theory in Action. Vol. 5. No. 1, 2012. Ali Shehzad Zaidi, ed. New Jersey: Transformative Studies Institute. The issue is dedicated to the work of Mircea Eliade. It includes Eliade's four-act play A Spiritual Adventure (Aventură Spirituală) in English translation by Mac Lonscott Ricketts.

Tópicos del Seminario. 25. Benemérita Universidad Autónoma de Puebla. 2011. ISSN 1165-1200. (Dir. María Isabel Filinich). Under the title "La traducción, perspectivas actuales" (Victor Ivanovici, ed.) it contains articles in Spanish by F. Rastier, C. Calfoglou, D. Connolly, I. Even-Zohar, V. Ivanovici, L. Venuti.

Tópicos del Seminario. 26. Benemérita Universidad Autónoma de Puebla. 2011. ISSN 165-1200. (Dir. María Isabel Filinich). Under the title "Formas de la lentitud" it contains a number of articles in Spanish.

Translation. A Transdisciplinary Journal. Inaugural Issue, 2011. Fondazione Universitaria San Pellegrino. It cointains a number of short essays on different practical and theoretical issues of translation. $87 \mathrm{pp}$. ISBN 978-88.6372-370-0.

Tronch-Pérez, Jesús. A Synoptic Hamlet. Valencia: Universitat de València, 2002. 407 pp. ISBN 84-370-5381-1. 